SZCZEPAN KOZAK

https://orcid.org/0000-0003-2198-7054

Uniwersytet Rzeszowski

\title{
AKTYWNOŚĆ ZAWODOWA LUDZI STARYCH W GALICJI W POCZAৃTKACH XX W. ZARYS STATYSTYCZNY
}

Zarys treści: Artykuł poświęcony jest aktywności zawodowej ludności w wieku 60+ zamieszkującej Galicję w pierwszym dziesięcioleciu XX w., widzianej przez pryzmat danych ilościowych. Głównym źródłem są wyniki spisów powszechnych z lat 1900 i 1910, publikowane na łamach wydawnictw „Österreichische Statistik” i „Österreichische Statistik. Neue Folge”. Analiza statystyczna tych materiałów prowadzi do konkluzji o znacznej aktywizacji ludzi starych, pozwala na wyodrębnienie jej cech charakterystycznych oraz trzech modeli realizacji zawodowej.

The content outline: The article deals with the issue of professional activity of the elderly over the age of 60 living in Galicia in the first decade of the twentieth century, analysed on the basis of quantitative data. The main source for the analysis are the censuses of 1900 and 1910, published in the volumes of Österreichische Statistik and Österreichische Statistik. Neue Folge. Statistical analysis of the source material shows a large degree of professional mobilization of the elderly and allows to indicate its characteristic features and develop three models of professional activity.

Słowa kluczowe: Galicja, starość, struktura zawodowa, praca

Keywords: Galicia, old age, professional structure, work

\section{Wstęp}

W powieści Ziemia obiecana znajdujemy fragment przedstawiający jednego z robotników fabryki Hermana Bucholca skarżącego się głównemu bohaterowi Karolowi Borowieckiemu na mające nastapić zwolnienia po zamontowaniu nowych maszyn. W odpowiedzi słyszy, że znajdzie sobie pracę gdzie indziej, a w fabryce pozostaną tylko osoby z dłuższym 
stażem $^{1}$. Nie byłoby w tym nic nadzwyczajnego, jednak w adaptacji filmowej w rolę owego robotnika wcielił się 68-letni wówczas aktor Witold Dederko ${ }^{2}$. Wersja filmowa nadała temu epizodowi nieoczekiwanie nowy wyraz, a reżyserskie wyobrażenie dziewiętnastowiecznych realiów zawodowych zostało bardzo sugestywnie podkreślone gra aktorska.

Choć między fabrycznym światem Łodzi a rolniczą Galicją istniała przepaść, scena ta skłania do refleksji na temat aktywności zawodowej grupy ludności, która dziś cieszy się przywilejami wynikającymi z wieku emerytalnego. Zagadnienie to wydaje się również interesujace z punktu widzenia dyskusji toczącej się wokół podniesienia jego granicy w latach 2013-2017. Według danych GUS w 2014 r. osoby w wieku 60 i więcej lat stanowiły w Polsce ponad $20 \%$ społeczeństwa ${ }^{3}$, a współczynnik ich aktywności zawodowej wynosił ok. 12,2 (29,8 wśród osób w wieku 60-64 lat i 4,5 w grupie $\left.65^{+}\right)^{4}$. Prognozy na dalsze lata wskazuja na pogłębianie się tego zjawiska, według danych Eurostatu w 2060 r. ok. 34\% ludności Polski przekroczy 65. rok życia ${ }^{5}$.

Dostrzegalne od kilku lat zjawisko dysproporcji generacyjnej kieruje uwagę ekonomistów na aktywizację osób starych. Zgodnie z teorią rozwoju gospodarczego ich potencjał zawodowy stanowi dziś istotny bodziec wzrostu współczesnych krajów rozwiniętych ${ }^{6}$. Wśród atutów tej grupy pracowniczej wymienia się m.in. doświadczenie, wiedzę, wykształcenie, wysoki kapitał społeczny oraz - co szczególnie istotne - fakt, że moga podnosić kompetencje młodszych pracowników, będąc dla nich źródłem tzw. cichej wiedzy ${ }^{7}$. Próby ich zatrzymania na rynku pracy owocuja zarówno różnymi zachętami ekonomicznymi, jak i zmianami wieku

${ }^{1}$ W. Reymont, Ziemia obiecana, b.d. i m.w., s. 14.

${ }^{2}$ Witold Dederko (1906-1988), obok aktorstwa znany był także jako fotoreporter i autor kilkunastu książek o tematyce fotograficznej, a także wykładowca Państwowej Wyższej Szkoły Filmowej oraz Państwowej Wyższej Szkoły Filmowej i Teatralnej im. Leona Schillera w Łodzi. Zagrał w ponad 20 filmach, przeważnie role drugoplanowe.

${ }_{3}$ Stan i struktura ludności oraz ruch naturalny $w$ przekroju terytorialnym $w 2014$ r. Stan w dniu 31 XII, Warszawa 2015, s. 18-19. W wieku poprodukcyjnym (60+ dla kobiet i $65+$ dla mężczyzn) było nieco mniej - 19\%.

${ }^{4}$ Rocznik statystyczny pracy, Warszawa 2015, s. 99-102.

${ }^{5}$ Cyt. za: A. Libertowska, Sytuacja osób $w$ wieku 50+ na rynku pracy $w$ Polsce wobec przemian demograficznych, „Zeszyty Naukowe Politechniki Poznańskiej” 2017, nr 75, s. 166; zob. też https://forsal.pl/artykuly/819139,raport-moody-s-kryzysdemograficzny-uderzy-w-swiatowa-gospodarke.html (3 XI 2019).

${ }^{6}$ A. Niewiadomska, Aktywność zawodowa osób starszych w wybranych krajach Europy Środkowej, „Ekonomia XXI wieku” 2016, nr 3 (11), s. 311-326.

${ }_{7}$ M. Majewska, K. Przybylczak, Aktywność zawodowa osób starszych warunkiem utrzymania produktywności $w$ krajach gospodarczo rozwiniętych, „Studia i Prace WNEiZ US” 2018, nr 52/3, s. 227. 
emerytalnego. Pomimo to w latach 2004-2014 w Europie Środkowej ogólny poziom aktywności zawodowej seniorów określano jako niski (ok. 10\% osób powyżej 65. roku życia), choć sytuacja w poszczególnych krajach jest zróżnicowana ${ }^{8}$.

Realia dziewiętnastowieczne nie znały tego problemu, aczkolwiek nasuwaja pewne ograniczone analogie ze współczesnymi krajami rozwijajacymi się o słabszej gospodarce, dla których zatrudnianie seniorów nie ma tak istotnego znaczenia. Specyfika rynku pracy z dominacją sektora rolniczego - a taki niewątpliwie charakteryzował wówczas monarchię Habsburgów - powodowała, że potencjał gospodarczy kraju przez wiele lat uzależniony był głównie od młodych pracowników fizycznych? ${ }^{9}$. Pomimo agrarnego charakteru gospodarka Austrii ulegała stopniowo, choć nierównomiernie, modernizacji w ciagu całego stulecia. Ustępując takim potęgom jak Anglia, Niemcy czy Francja, wykształciła ośrodki przemysłowe m.in. w Czechach, Morawach, na Ślasku oraz mniejsze skupiska fabryczne na obszarze Austrii Górnej i Dolnej ${ }^{10}$. Same tylko Czechy i Morawy przed I wojna światowa partycypowały w 56\% produkcji przemysłowej austriackich krajów koronnych, podczas gdy Galicja i Bukowina w zaledwie $9 \%{ }^{11}$.

Zachodzace w drugiej połowie XIX w. procesy modernizacyjne, których stymulatorem był rozwój przemysłu i towarzyszący mu postęp technologiczny, generowały zapotrzebowanie już nie tylko na młodych, ale wykształconych i wykwalifikowanych pracowników. Wymienione wyżej atuty dzisiejszych seniorów niekoniecznie musiały cechować ich starszych poprzedników, a warunki fizjologiczne nie podnosiły ich konkurencyjności i nie odpowiadały potrzebom ówczesnego rynku pracy ciagle jeszcze agrarnej gospodarki tej części Europy. Na przełomie XIX i XX w. seniorzy w większości nie byli ani tak sprawni fizycznie jak ich znacznie młodsi konkurenci, ani specjalnie wykształceni. Można w tym miejscu postawić hipotezę, że jako osoby, które urodziły się w latach czterdziestych i pięćdziesiątych XIX w., pozostali w cieniu długotrwałego opóźnienia gospodarczego. Zarówno wiek, jak i doświadczenie zawodowe, jakim w większości dysponowali, nie podnosiły ich atrakcyjności na rynku pracy. Perspektywa zasilenia rzeszy niewykwalifikowanych

8 Najwyższe wskaźniki cechowały Estonię (26\% osób powyżej 65. roku życia), najniższe - Słowację i Węgry (4\% osób w wieku 65-69 lat); szerzej zob. A. Niewiadomska, dz. cyt., s. 321.

${ }_{9}$ M. Majewska, K. Przybylczak, dz. cyt., s. 227.

${ }^{10}$ R. Tomczyk, Prawo pracownicze $w$ dobie industrializacji $w$ monarchii habsburskiej, „Historia Slavorum Occidentis” 2016, nr 1 (10), s. 167-169.

11 Tamże, s. 169. 
robotników, bez stałego zatrudnienia, nie należała do zbyt optymistycznych wizji starości, nie gwarantowała stabilizacji ekonomicznej ${ }^{12}$. Istotne staje się zatem pytanie o strategie życiowe przyjmowane $\mathrm{w}$ tym okresie życia.

\section{Przedmiot badań i źródło}

Kwestia udziału seniorów w rynku pracy nie jest problemem obcym badaniom naukowym. Przyznać jednak należy, że zainteresowanie takie przejawiało się raczej w obszarze pozahistorycznym, jako reakcja na różne problemy związane ze współczesnościa ${ }^{13}$. Postępowanie badawcze opierało się często na ankietyzacji próby reprezentatywnej i dostępnym materiale statystycznym. Przeniesienie tego wzorca na społeczności historyczne jest możliwe, ale ze zrozumiałych względów wymaga modyfikacji. Istniejące statystyki urzędowe, publikowane na łamach wydawnictw dziewiętnastowiecznych, sa różnej jakości, a analiza rozmaitych aspektów aktywności zawodowej (np. poprzez powiązanie z miejscem zajmowanym w hierarchii społecznej, rodzinnej; samorealizacja, wartościa pracy czy kondycją zdrowotna), dla której dane czerpie się współcześnie m.in. z ankiet, wymaga szerokich kwerend źródłowych. Problem jest o tyle istotny, że spojrzenie na ludzi starych jako część społeczeństwa Galicji, pomijając nawet interesujacy nas aspekt pracy, ciagle znajduje się w obszarze postulatów badawczych. Wybrane zagadnienia rozproszone sa w publikacjach poświęconych szerszej tematyce ${ }^{14}$. Jeśli odwołać się do dwutomowego dzieła Ludzie starzy i starość na ziemiach polskich od XVIII do XXI wieku ${ }^{15}$, próżno tam szukać wątków galicyj-

${ }^{12}$ M. Majewska, K. Przybylczak, dz. cyt., s. 227.

${ }_{13}$ Por. dla przykładu: T. Borkowska-Kalwas, Aktywność zawodowa ludzi starych, w: Starzy ludzie w Polsce. Społeczne i zdrowotne skutki starzenia sie spoteczeństwa, red. J. Halik, Warszawa 2002, s. 49-52; M. Majewska, K. Przybylczak, dz. cyt.; A. Niewiadomska, dz. cyt.; N.G. Pikuła, Rozwój zawodowy $i$ zawodowa satysfakcja w perspektywie osób starszych, „Labor et Educatio” 2016, nr 4, s. 201-217; M. Podogrodzka, Wybrane miary starości demograficznej $i$ ich implikacje dla oceny przestrzennego zróżnicowania tego zjawiska w Polsce, „Studia Ekonomiczne. Zeszyty Naukowe Uniwersytetu Ekonomicznego w Katowicach” 2016, nr 289, s. 98-107; J. Staręga, Ludzie starzy a praca zawodowa, Warszawa 1976. W badaniach historycznych problem ten jest rzadko podejmowany i przeważnie zatomizowany.

${ }^{14}$ Por. B. Gapiński, Ludzie starzy na wsi polskiej od schytku XIX wieku po rok 1939, Poznań 2014.

${ }^{15}$ Ludzie starzy $i$ starość na ziemiach polskich od XVIII do XXI wieku (na tle porównawczym), t. 1-2, red. A. Jasińska-Janiak, K. Sierakowska, A. Szwarc, Warszawa 2016. 
skich wyodrębnionych tak wyraźnie jak w przypadku innych ziem polskich tego okresu ${ }^{16}$.

Starość znana z autopsji nie do końca pokrywa się ze stosowanymi $\mathrm{w}$ nauce kryteriami. O tym, że trudno ją ująć w formalne ramy (zważywszy, że stanowi dodatkowo subiektywne doświadczenie jednostki) świadczy choćby wielość definicji, etapizacja i w efekcie zróżnicowanie cezury wieku emerytalnego ${ }^{17}$. Współcześnie za początek tego etapu egzystencji uważa się granicę 60 . roku życia ${ }^{18}$ i taka też przyjmiemy $\mathrm{w}$ niniejszych rozważaniach. Jest to zarazem okres wiązany ze schyłkiem aktywności zawodowej (por. wiek emerytalny lub poprodukcyjny).

Obowiazujace na terenie Austrii przepisy prawa pracy były rozproszone, cały zaś jego system określany jako skomplikowany i niespójny ${ }^{19}$. Poszczególne rozwiazania wchodziły w zakres prawa administracyjnego, jako ustawodawstwo fabryczne ${ }^{20}$. W drugiej połowie XIX w. w przemyśle i rzemiośle podejmowano próby jego kodyfikacji, czego efektem była m.in. tzw. ordynacja przemysłowa z 20 XII 1859 r. (wprowadzona patentem cesarskim z 1 V 1860 r.), znowelizowana 8 III 1885 r. (kolejne zmiany: 23 II 1897, 5 II 1907 r. $^{21}$ ). Uregulowania te, odnosząc się do tzw. robotników przemysłowych, pozostawiały poza nawiasem całkiem spore grupy pracowników najemnych (np. robotników dniówkowych), z drugiej zaś strony nie dotyczyły osób zatrudnionych w innych działach, np. administracji $^{22}$. Przykładowo w sektorze służby publicznej (zarówno krajowej,

${ }^{16}$ Wyjątek stanowia teksty Stefana Ciary i Tomasza Pudłockiego; zob. S. Ciara, Starość ludzi nauki w Krakowie i Lwowie w końcu XIX i w pierwszej ćwierci XX wieku (na wybranych przykładach), w: tamże, t. 2, s. 65-71; T. Pudłocki, Czy na pewno starzy? Obraz profesorów i nauczycieli szkót średnich Galicji z drugiej połowy XIX i poczatku XX wieku w oczach ich uczniów, w: tamże, s. 325-337.

${ }_{17}$ Przykładowo według Światowej Organizacji Zdrowia (WHO) starość rozpoczyna się od 60. roku życia i dzieli na trzy etapy (60-75, 75-90, ponad 90 lat). Według ONZ gdy 7\% ogółu ludności przekroczy 65. rok życia populacja uważana jest za stara.

18 J.-P. Bois, Historia starości. Od Montaigne'a do pierwszych emerytur, tłum. K. Marczewska, Warszawa 1996, s. 14.

${ }_{19}$ Por. M. Nietyksza, Ramy prawne zarobkowania kobiet $w$ Królestwie Polskim $w$ XIX i na poczatku XX w. na tle porównawczym, w: Kobieta i praca. Wiek XIX i XX. Zbiór studiów, t. 6, red. A. Żarnowska, A. Szwarc, Warszawa 2000, s. 26.

${ }^{20}$ R. Tomczyk, dz. cyt., s. 173.

${ }^{21}$ D.P. Kruk, Instytucjonalne formy wspierania rozwoju przemystu Galicji $w$ dobie autonomii, „Zeszyty Naukowe Uniwersytetu Ekonomicznego w Krakowie” 2015, nr 6 (942), s. 99.

${ }^{22}$ Ordynacji nie podlegały „przedsiębiorstwa i zawody” takie jak: rolnictwo i leśnictwo, górnictwo, zawody literackie i artystyczne, gospodarstwo domowe, adwokatura, notariat, pośrednictwo handlowe, inżynieria, lecznictwo, zakłady lecznicze, aptekarstwo, weterynaria, nauczycielstwo prywatne, pracownicy zakładów filantropijnych, szkół zawodowych, zakładów karnych i poprawczych, pracownicyinstytucji kredytowych 
jak i państwowej) stanowisko prawne zatrudnionych regulowało wiele szczegółowych przepisów, uwzględniających zróżnicowanie na administrację państwowa, sądownictwo, wojsko, oświatę itp. ${ }^{23}$

Zróżnicowana była również forma stosunku pracy. Zatrudnienie robotników przemysłowych opierało się na umowie najmu usług, wywodzącej się jeszcze z Allgemeines Bürgerliches Gesetzbuch (§ 1151$-1174)^{24}$, pracownicy służby publicznej obejmowali stanowisko na podstawie nominacji, często poprzedzonej egzaminem. Należy też przypuszczać, że w wielu przypadkach, zwłaszcza tam, gdzie zatrudnienie miało charakter okazjonalny, obywano się bez zbytniej formalizacji, bazując na normach zwyczajowych.

Wzmiankowane przepisy prawa pracowniczego z dużą szczegółowością precyzowały dolną granicę wieku wejścia na rynek pracy, różnicując ją w zależności od sektora i charakteru zatrudnienia (w granicach od 12. do 14. i 16. roku życia) ${ }^{25}$. Nie istniały natomiast żadne powszechne ograniczenia górnej granicy wieku. Prawo emerytalne, mogące stanowić naturalną barierę, było wybiórcze i odnosiło się do ograniczonej grupy uprawnionych. Jeszcze w 1866 r. (na mocy rozporządzenia z 29 grudnia tr.) określono warunki przechodzenia na emeryturę urzędników państwowych - uzależniając ten fakt od stażu pracy ${ }^{26}$. Zwykle było to 40 lat, uprawniające do dożywotniej emerytury w wysokości ostatniej pensji ${ }^{27}$. W kolejnych latach ukazywały się szczegółowe rozporządzenia dotyczące poszczególnych grup urzędniczych. Obok wymaganych lat pracy określały one również wiek przejścia w stan spoczynku, który nie był jednolity. Przykładowo w myśl uregulowań prawnych z 1870 r. dla nauczycieli granica ta wynosiła 65 lat, dla nauczycieli akademickich zaś $70^{28}$. Możliwe było również przejście na wcześniejszą emeryturę

i bankowych, zastawniczych, asekuracyjnych, kas oszczędności oraz ochronek, pracownicy kolei żelaznej, żeglugi parowej i morskiej, transportu, przedsiębiorstw zabaw publicznych i rozrywki, a także wydawnictw i osoby trudniące się handlem okrężnym; szerzej zob. I. Suesser, Prawa i obowiazki robotników wedtug ustaw austriackich, Kraków b.d.w., s. 8.

${ }^{23}$ K. Broński, Rozwój system ubezpieczeń społecznych w Galicji w XIX wieku (zarys problematyki), „Zeszyty Naukowe Uniwersytetu Ekonomicznego w Krakowie” 2010, nr 824, s. 21.

${ }^{24}$ „Allgemeines Bürgerliches Gesetzbuch” 1811; zob. I. Suesser, dz. cyt., s. 6.

${ }_{25}$ I. Suesser, dz. cyt., s. 8-9.

${ }^{26}$ R. Tomczyk, Pragmatyka służbowa ze szczególnym uwzględnieniem prawodawstwa płacowo-emerytalnego $w$ monarchii konstytucyjnej $w$ Austrii przed duża nowelizacja w 1914 roku, ,Zeszyty Naukowe Uniwersytetu Rzeszowskiego. Seria Prawnicza” 2013, nr 77, s. 161.

${ }^{27}$ K. Broński, dz. cyt., s. 21.

${ }^{28}$ R. Tomczyk, Pragmatyka..., s. 167. 
po osiagnięciu 60. roku życia i przy 35-letnim stażu pracy ${ }^{29}$. Ustawa z 16 XII 1906 r. doprowadziła do rozszerzenia obowiazkowego ubezpieczenie emerytalnego na pracowników umysłowych spoza administracji państwowej, co faktycznie nastapiło dopiero od 1 I 1909 r. ${ }^{30}$

Przed I wojna światową emerytura nie była więc zjawiskiem powszechnym, przechodzenie w stan spoczynku nie miało charakteru masowego i dotyczyło wybranych, nielicznych grup zawodowych ${ }^{31}$. Konieczność pracy stawała się obowiazkiem dożywotnim i tylko wypadki losowe lub zdrowotne mogły usprawiedliwić jej zaniechanie. Nie istniała formalna granica wieku ograniczająca aktywność zawodowa, a sytuacja gospodarcza Galicji sprawiała, że nie było też przesłanek ekonomicznych zachęcajacych do podjęcia takiego kroku. Nie występowało zjawisko znane współcześnie pod nazwą retirement push \& pull factors, obniżające aktywność zawodową osób w wieku okołoemerytalnym ${ }^{32}$.

Celem niniejszego artykułu jest ukazanie skali aktywności zawodowej mieszkańców Galicji przekraczających 60. rok życia oraz jej charakterystycznych cech przez pryzmat struktury zawodowej.

Źródłem będącym podstawą przedstawionych niżej wniosków są wyniki spisów ludności z 1900 i 1910 r. publikowane na łamach „Österreichische Statistik" ${ }^{33}$. Materiały ujęte w tabele zbiorcze wydano drukiem w 1904 i $1916 \mathrm{r} .{ }^{34} \mathrm{~W}$ porównaniu z wcześniejszymi roczniki te sa bardziej szczegółowe, zawierając m.in. osobne zestawienia obrazujące główne źródła utrzymania według grup wiekowych. Spis ludności z $1900 \mathrm{r}$. grupuje ludność według wieku w 10-letnich przedziałach, spis z 1910 r. jest pod tym względem bardziej precyzyjny, stosując przedziały 5-letnie. Pomimo

${ }^{29}$ Tamże, s. 173.

${ }^{30}$ K. Broński, dz. cyt., s. 21-22.

${ }^{31}$ Por. L.A. Zyblikiewicz, Ludność Krakowa w drugiej połowie XIX wieku. Struktura demograficzna, zawodowa $i$ społeczna, Kraków 2014, s. 187 n.

32 A. Libertowska, dz. cyt., s. 169.

33 „Österreichische Statistik” 66, 1904, nr 11, s. 182-205; „Österreichische Statistik. Neue Folge” 3, 1916, nr 10, s. 206-221.

${ }^{34}$ Szerzej nt. spisów ludności zob. A. Burzyński, Statystyka austriacka i krajowa jako źródto do badań nad strukturq społeczno-zawodowq zatrudnionych w przemyśle ciężkim w Galicji, „Studia Historyczne” 26, 1983, nr 2 (101), s. 223-242; tenże, Z rozważań nad ocenq austriackich powszechnych spisów ludności z lat 1869-1919, „Przeszłość Demograficzna Polski” 15, 1984, s. 58-69; T. Gasowski, Austriackie spisy ludności z lat 1869-1910, „Przeszłość Demograficzna Polski” 13, 1981, s. 37-48; K. Zamorski, Informator statystyczny do dziejów społeczno-gospodarczych Galicji. Ludność Galicji w latach 1857-1910, Kraków-Warszawa 1989; L.A. Zyblikiewicz, Powszechne spisy ludności w monarchii Habsburgów, w: Celem nauki jest człowiek... Studia z historii społecznej i gospodarczej ofiarowane Helenie Madurowicz-Urbańskiej, red. P. Franaszek, Kraków 2000, s. 387-400. 
to w obu przypadkach prezentacja kategorii zawodowych i wieku pracujacych jest ograniczona podstawowym punktem odniesienia, jaki stanowi cała ludność Galicji, z uwzględnieniem jedynie płci i stanu cywilnego. Chociaż przy opracowaniu danych spisowych zestawiono zarówno strukturę wyznaniowa, językowa, jak i podział administracyjny prowincji, to jednak nie powiązano tych parametrów $\mathrm{z}$ wiekiem i wykonywanym zawodem - co znacznie ograniczyło możliwości analizy statystycznej.

Obydwa spisy różnią się zakresem prezentacji materiału. Tabele dla 1900 r. informują o liczbie ludności pracującej według wieku w czterech głównych sektorach, wraz z ich szczegółowym rozwarstwieniem na 30 grup zawodowych. W spisie z $1910 \mathrm{r}$. związek wieku z zatrudnieniem potraktowano ubocznie, zatrzymując się na poziome czterech sektorów (pominięto na tym etapie szczegółowe kategorie zawodowe). Różnice te utrudniają obserwację zjawiska w czasie.

\section{Ludność aktywna zawodowo w wieku 60+ na tle pozostałych grup wiekowych}

Osoby w wieku 60 i więcej lat zamieszkujące ziemie zaboru austriackiego w drugiej połowie XIX w. tworzyły niewielką grupę, której udział w stosunku do pozostałych wzrastał na przestrzeni 50 lat, ale nie przekroczył $6 \%{ }^{35}$. Pod względem demograficznym było to społeczeństwo stosunkowo młode ${ }^{36}$.

Jeśli wierzyć statystykom austriackim, na początku XX w. poszczególne grupy wiekowe wkraczały w obszar rynku pracy stopniowo (zob. wykresy 1-2). Apogeum aktywności zawodowej charakteryzowało roczniki w wieku powyżej 40 lat, z wyraźnie zaznaczająca się różnica płci (dla mężczyzn ponad 90\%, dla kobiet ok. 80\%). Obniżenie się tego poziomu obserwujemy w przypadku kobiet już po przekroczeniu 50. roku życia, podczas gdy u mężczyzn utrzymywał się aż do osiagnięcia wieku 60 lat. Materiały z 1910 r. wskazują na wydłużenie się okresu wysokiej aktywności w obu przypadkach do ok. 65. roku życia, z ciagle dostrzegalną dysproporcją między kobietami i mężczyznami. W 1900 r. udział mężczyzn bez zatrudnienia między 60. a 70. rokiem

${ }^{35} \mathrm{~W}$ kolejnych latach spisowych wskaźnik starości Galicji liczony według skali Rosseta wynosił: 1857 - 2,44; 1869 - 3,60; 1880 - 4,61; 1890 - 5,05; 1900 - 5,90; 1910 - 5,49; obliczenia własne na podstawie: K. Zamorski, Informator statystyczny do dziejów społeczno-gospodarczych Galicji..., passim.

${ }^{36}$ Zob. też M. Tymiński, P. Koryś, Struktura zawodowa ziem polskich na przełomie XIX $i$ XXw., RDSG, t. 75, 2015, s. 148 (tab. 2). 
Wykres 1. Aktywność zawodowa ludności Galicji w 1900 r. według grup wiekowych
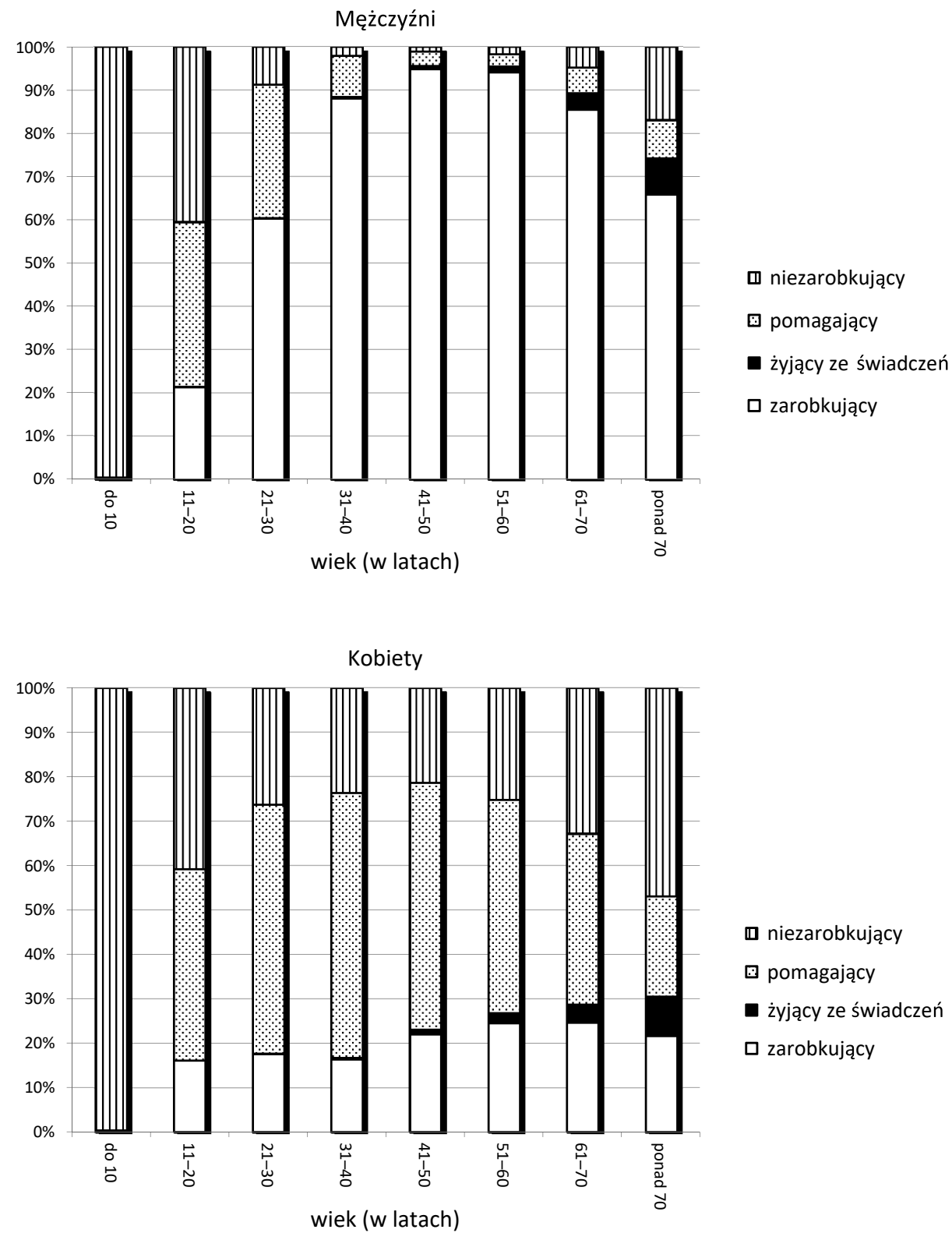

Źródło: obliczenia własne na podstawie: „Österreichische Statistik” 66, 1904, nr 11, s. 182-205. 
Wykres 2. Aktywność zawodowa ludności Galicji w 1910 r. według grup wiekowych
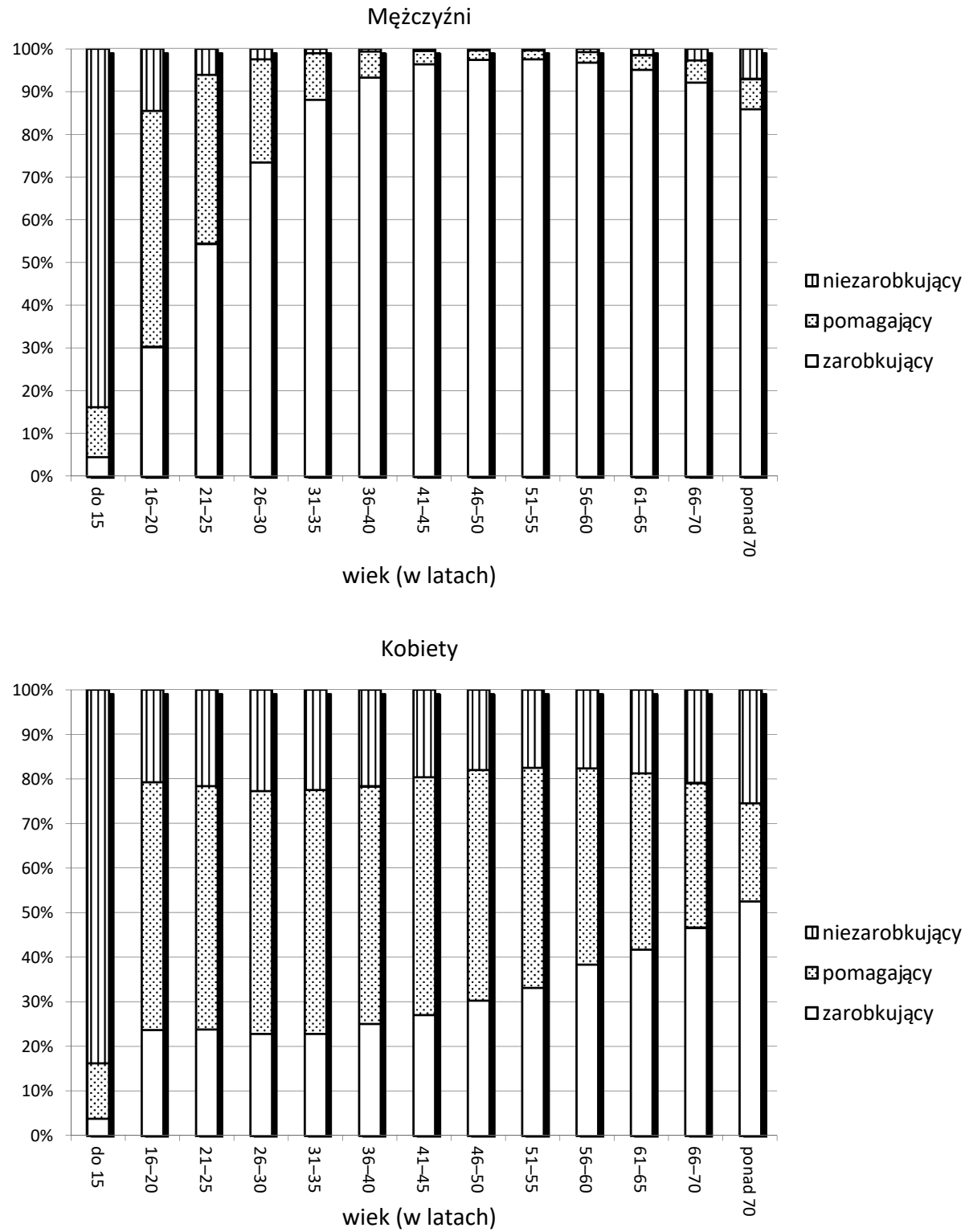

Źródło: obliczenia własne na podstawie: „Österreichische Statistik. Neue Folge” 3, 1916, nr 10, s. 206-221. 
życia $\mathrm{w}$ porównaniu $\mathrm{z}$ dzisiejszymi standardami można uznać za niewielki (ok. 10\%). Dopiero w ostatnim przedziale (po 70. roku życia) dał się zauważyć większy spadek aktywności, który jednakże mógł być spowodowany błędem grupowania nieuwzględniającego górnej granicy (mimo to pracowało aż $2 / 3 \mathrm{z}$ nich).

Mniejszy był poziom aktywności zawodowej kobiet we wszystkich grupach wiekowych ${ }^{37}$. W 1900 r. najwyższy, blisko 80-procentowy wskaźnik osiagnęły po przekroczeniu 40. roku życia (mężczyźni - ok. 98\%). Dokładniejsze dane z 1910 r. wskazuja ponadto na dość wczesna stabilizację. Podobnie wysoki wskaźnik charakteryzował już kobiety w wieku od 16 do 70 lat (w przypadku mężczyzn stabilizacja zaczynała się później dopiero po 30. roku życia - na poziomie 98-99\%). Po 70. roku życia bez źródła utrzymania pozostawała około połowa kobiet w 1900 i 25\% w 1910 r. Można jednak założyć, że w tym ostatnim przypadku statystyki były zawyżone.

Mówiąc zatem o aktywności zawodowej seniorów w Galicji na początku XX w., musimy wstępnie przyznać, że była ona nieco zróżnicowana, ale wysoka. Zaznaczające się dysproporcje między mężczyznami i kobietami stanowiły odzwierciedlenie i zarazem kontynuację upośledzenia tych ostatnich na rynku pracy, którego źródeł szukać należy znacznie głębiej niż tylko w podeszłym wieku ${ }^{38}$.

Spisy ludności z tego okresu uwzględniały również kilka innych elementów, które dodatkowo moga wzbogacić nasze pojęcie na temat specyfiki ówczesnych realiów zawodowych w grupie ludzi starych. Wśród osób pracujących na uwagę zasługuje osobno wyodrębniona grupa tzw. pomagających członków rodziny. W rolniczej Galicji nawet u progu XX w. traktowanie rodziny jako wspólnoty gospodarczej było bardzo powszechne. Pomoc ze strony żony i dzieci w zarobkowaniu nie była formalnie wynagradzana ${ }^{39}$, zreszta statystyki austriackie zwróciły uwage na tę grupę ludności dość późno, po raz pierwszy dopiero w 1900 r. Wcześniej zaliczano ich prawdopodobnie do ogółu pracujacych, choć trudno dziś dywagować, do jakiego stopnia konsekwentnie. Taka forma aktywności w stosunkach zawodowych modernizującego się społeczeństwie traktowana jest jednak jako anachronizm ${ }^{40}$.

${ }_{37}$ Por. S. Kozak, Kierunki aktywizacji zawodowej kobiet $w$ Galicji w końcu XIX i na poczqtku XX wieku w świetle spisów ludności „Zeszyty Naukowe UJ. Prace Historyczne" 2019, z. 146, nr 1, s. 101-128.

${ }^{38}$ Por. tamże, s. 116, 119.

${ }^{39}$ Nie chodzi tu o prace pomocnicze we współczesnym tego słowa znaczeniu, wykonywane w gospodarstwie domowym.

${ }^{40}$ A. Żarnowska, Praca zarobkowa kobiet $i$ ich aspiracje zawodowe $w$ środowisku robotniczym i inteligenckim na przetomie XIX $i$ XX wieku, w: Kobieta i praca..., s. 42. 
Pozornie do roli tej seniorzy wydają się niemal predestynowani. Zarówno dla osób starych (z uwagi na przypadłości wieku), jak też kobiet i dzieci funkcjonujących w społecznościach patriarchalnych (preferujacych tradycyjny podział ról społecznych) pomocniczy charakter wydawałby się naturalnym stanem ich aktywności ${ }^{41}$. Przyglądając się relacjom zawodowym kobiet i mężczyzn w Galicji, trudno nie zauważyć, że w większości przypadków tak właśnie było (zob. wykresy 1-2), choć skala zjawiska różnicowała się w zależności od miejsca, czasu oraz pozycji społecznej i oczywiście wieku ${ }^{42}$. Obok kobiet tzw. pomagającym był też co trzeci mężczyzna przed ukończeniem 30 lat.

Wśród osób powyżej 60. roku życia obraz ten nieco się zmieniał (zob. wykresy 1-2). Udział tzw. pomagających członków rodziny zwłaszcza wśród mężczyzn w wieku 60+ podobnie jak w młodszych grupach wiekowych (30+) nie przekraczał 10\% (tyle samo co bierni zawodowo). Co prawda skala tego zjawiska w 1900 i 1910 r. różniła się, ale ogólne tendencje były zbliżone. Największą grupę stanowili zarobkujący, czyli zatrudnieni w pełnym tego słowa znaczeniu (tzn. samozatrudnieni/ samodzielni, pracownicy umysłowi, robotnicy). Ich proporcjonalny udział obniżał się z wiekiem (w 1900 z 85\% do 65\%; w 1910 z 95\% do 85\%), co w tej grupie wiekowej mogło być wynikiem większego oddziaływania czynników fizjologicznych. Wątpliwości budzą jednak wysokie wskaźniki z 1910 r., kiedy to do osób pracujących zaliczono również korzystających z zasiłków, bez wyraźnego wyodrębnienia.

Nieco inaczej to zjawisko kształtowało się wśród kobiet, dla których rola pomocniczego członka rodziny jako forma aktywności zawodowej była bardzo popularna w całym okresie życia (zob. wykresy $1-2$ ). W ich przypadku po osiagnięciu starości dostrzegalna jest jednak tendencja w kierunku odwrócenia proporcji. Jeśli w 1900 r. ok. 60\% kobiet w wieku 31-40 lat odnotowano jako tzw. pomagające, to między 60. a 70. rokiem życia wskaźnik ten spadł do ok. 40\%, przy czym udział zarobkujących zwiększył się do 1/4. Po 70. roku życia ich aktywność w ogóle się obniżała, w przypadku kobiet zarobkujących był to spadek niewielki (ciagle utrzymywały się na poziomie ponad $20 \%$ ), podczas gdy ich udział jako tzw. pomagających zmniejszył się niemal dwukrotnie.

Czy w świetle tych danych możemy mówić o jakiejś formie awansu? Niewątpliwie po przekroczeniu 60. roku życia aktywność zawodowa w obu przypadkach - tak mężczyzn, jak i kobiet - obniżała się

${ }^{41}$ Por. B. Gapiński, dz. cyt., s. 125-145.

${ }^{42}$ S. Kozak, dz. cyt.; zob. też tenże, Kobieta na prowincji galicyjskiej w świetle akt notarialnych 1871-1914. Studium historyczno-źródtoznawcze, Rzeszów 2013. 
w stosunku do młodszych grup wiekowych. W większym jednak stopniu na rynku pracy pozostawały osoby określane jako zarobkujące, a więc prawdopodobnie posiadające pewne kwalifikacje zawodowe.

Jaki był charakter tej pracy, czy istniały szczególnie preferowane w tym okresie życia zajęcia? Nie ma zbyt wielu opracowań, które rzucałyby więcej światła na te zagadnienia. Bartłomiej Gapiński, zajmując się problematyką ludzi starych na wsi polskiej, zwraca uwagę na pewien zakres tolerancji wobec bierności zawodowej seniorów, z uwagi na dolegliwości wieku. Pracując w gospodarstwie wiejskim, byli zwolnieni z niektórych obowiązków. Z drugiej jednak strony brak zatrudnienia był źle postrzegany przez samych zainteresowanych, a poczucie nieużyteczności podkreślało różnice międzypokoleniowa. Dlatego zdaniem Gapińskiego ich obowiązki często zrównywane były z tymi, którymi obarczano małe dzieci ${ }^{43}$. Na ile statystyki to potwierdzaja, spróbujemy zweryfikować w dalszej części pracy, na pewno jednak charakterystyczna była w tym wieku różnorodność strategii życiowych, przejawiająca się w dążeniu seniorów do samowystarczalności. Nabyte doświadczenie życiowe sprzyjało wykonywaniu przez starych gospodarzy dorywczych prac np. z zakresu rzemiosła wiejskiego, kobiety trudniły się przędzalnictwem i tkactwem, a biedniejsi zbieractwem, w skrajnych przypadkach żebractwem ${ }^{44}$.

\section{Ludność w wieku 60+ według głównych sektorów gospodarki Galicji}

Statystyki austriackie rozróżniały cztery główne sektory gospodarki, $\mathrm{w}$ ramach których grupowały dane na temat zatrudnienia. Były to: A - rolnictwo, B - rzemiosło i przemysł (w tym górnictwo), C - handel i komunikacja, D - służba publiczna, wojsko, wolne zawody. Do tego ostatniego wliczano również osoby utrzymujące się z zasiłków, co jest o tyle ważne, że w grupach wiekowych 60+ mogły one stanowić poważną część.

Jak już wspomniano, obydwa analizowane spisy ludności różniły się nieco zakresem informacji, zwłaszcza jeśli chodzi o grupowanie według wieku. Spis z 1900 r. bardziej szczegółowo prezentował zróżnicowanie zawodowe (co uwzględniono w tab. 1), podczas gdy spis z 1910 r. ograniczył się do czterech powyższych sektorów, bez przedstawienia rozwarstwienia wewnętrznego (por. wykres 3).

\footnotetext{
${ }^{43}$ B. Gapiński, dz. cyt., s. 126.

${ }^{44}$ Tamże, s. 128-131.
} 
Tabela 1. Struktura aktywności zawodowej ludności Galicji według grup wiekowych i sektorów gospodarki w 1900 r. (bez wojskowych)

\begin{tabular}{|l|r|r|r|r|r|r|c|}
\hline \multirow{2}{*}{\multicolumn{1}{c|}{ Sektor gospodarki }} & \multicolumn{7}{|c|}{ Grupa wiekowa } \\
\cline { 2 - 8 } & $\mathbf{1 1 - 2 0}$ & $\mathbf{2 1 - 3 0}$ & $\mathbf{3 1 - 4 0}$ & $\mathbf{4 1 - 5 0}$ & $\mathbf{5 1 - 6 0}$ & $\mathbf{6 1 - 7 0}$ & $\begin{array}{c}\text { ponad } \\
\mathbf{7 0}\end{array}$ \\
\hline Rolnictwo & $84,93 \%$ & $76,33 \%$ & $82,41 \%$ & $83,49 \%$ & $79,11 \%$ & $81,92 \%$ & $71,08 \%$ \\
\hline Przemysł i rzemiosło & $5,32 \%$ & $6,26 \%$ & $6,44 \%$ & $5,90 \%$ & $6,57 \%$ & $4,48 \%$ & $3,77 \%$ \\
\hline Handel i komunikacja & $1,37 \%$ & $2,92 \%$ & $4,21 \%$ & $3,85 \%$ & $4,18 \%$ & $2,59 \%$ & $2,43 \%$ \\
\hline Służba publiczna i urzędnicy & $1,33 \%$ & $9,20 \%$ & $3,06 \%$ & $2,82 \%$ & $3,46 \%$ & $3,14 \%$ & $5,50 \%$ \\
\hline Służba domowa i wyrobnicy & $5,09 \%$ & $4,45 \%$ & $3,02 \%$ & $2,59 \%$ & $3,41 \%$ & $2,55 \%$ & $2,78 \%$ \\
\hline Na utrzymaniu/na zasiłku & $1,95 \%$ & $0,85 \%$ & $0,87 \%$ & $1,35 \%$ & $3,27 \%$ & $5,32 \%$ & $14,44 \%$ \\
\hline
\end{tabular}

Źródło: zob. wykres 1.

Wykres 3. Główne sektory zatrudnienia ludności Galicji w 1910 r. w poszczególnych grupach wiekowych

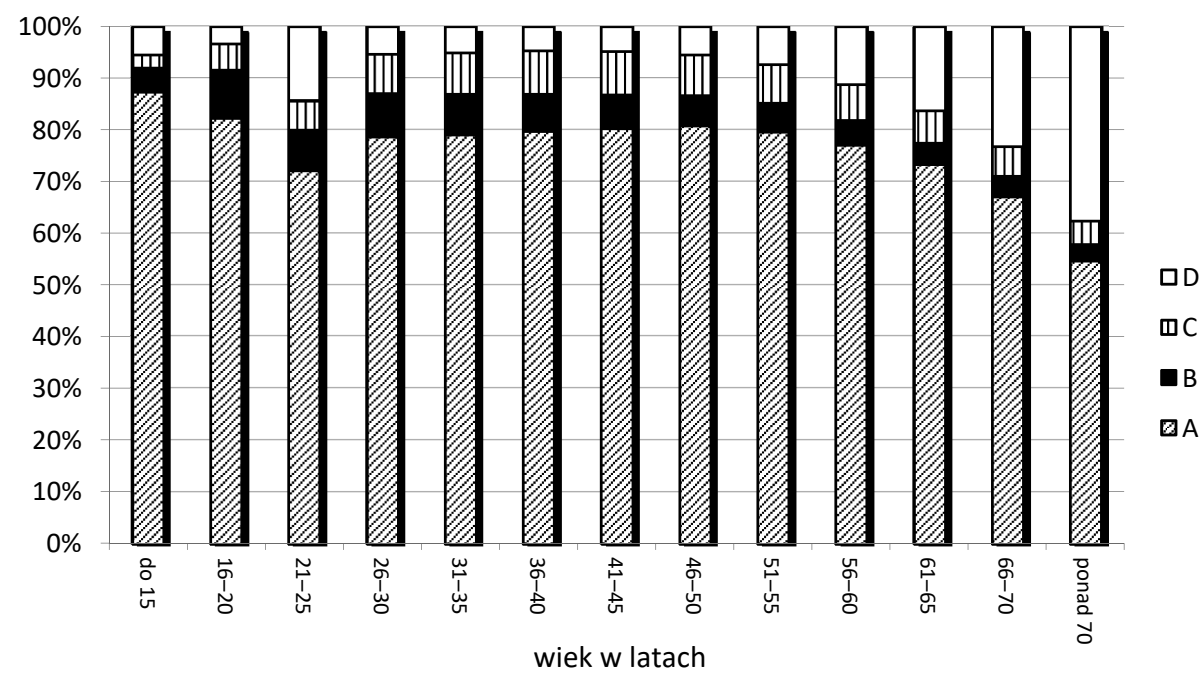

Legenda: A - rolnictwo, hodowla, leśnictwo, B - rzemiosło i przemysł, C - handel i komunikacja, D - służba publiczna, wojsko, wolne zawody, na zasiłku.

Źródło: zob. wykres 2.

Analiza danych z 1900 i 1910 r. pokazuje, że pomimo ogólnej dominacji, rolnictwo jako źródło utrzymania dla większości mieszkańców Galicji traciło jednak na rzecz sektora D w grupach wiekowych powyżej 55. roku życia (zob. wykres 3). Było to zjawisko bardzo wyraźne, zwłaszcza wśród osób osiągających wiek 70 i więcej lat, gdzie rola tego sektora wzrosła do prawie $40 \%$. Musimy jednak pamiętać o tym, że obejmował on ludność o dosyć zróżnicowanej i odległej nieraz orientacji 
zawodowej. Dla przykładu, aż 15\% udział osiagnał w grupie 21-25-latków (zob. wykresy 3-4) służących w armii austriackiej (licząc samych mężczyzn $-22 \%$ ). Jest wielce prawdopodobne, że podobny mechanizm zadziałał w grupie 60+, ale w tym wypadku za przyczyną beneficjentów różnych świadczeń socjalnych, którzy według spisu z 1910 r. we wszystkich grupach wiekowych liczyli ponad 126 tys. Przyjmując jako punkt odniesienia dokładniejsze dane z 1900 r., udało się oszacować, że wśród pozostających wówczas na zasiłkach osoby w wieku 60+ mogły stanowić ok. 46\%, co w przełożeniu na warunki z 1910 r. dałoby ok. 58 tys., czyli prawie 2/3 całego sektora. Prawdopodobnie wiec widoczny na wykresie proporcjonalny spadek aktywności zawodowej osób starych w rolnictwie wcale nie musiał przełożyć się na jej wzrost w sektorach pozarolniczych. Rosło po prostu znaczenie nieproduktywnych źródeł utrzymania, co z uwagi na wiek oraz fakt, że kobiety korzystały z nich dwukrotnie częściej wydaje się logicznym wytłumaczeniem. Warto tė̇ zauważyć, że był to wzrost nie tylko proporcjonalny, ale też ilościowy, $\mathrm{w}$ dodatku przeciwny do tendencji wspólnej dla pozostałych sektorów (zob. wykres 4). Gdyby wykluczyć osoby pobierające świadczenia, proporcje pomiędzy wszystkimi czterema sektorami w grupie 60+ ukształtowałyby się prawdopodobnie na poziomie charakteryzującym młodsze grupy wiekowe, od 26. roku życia poczynajac.

Szczegółowe preferencje zawodowe z uwzględnieniem konkretnych specjalizacji w sektorach pozarolniczych prezentuje wykres 5. Przy jego konstrukcji zrezygnowano z sektora $\mathrm{D}$, ponieważ połączono w nim różne źródła utrzymania, które dla ludności w wieku powyżej 60. roku życia miały częściowo uboczne znaczenie, były nieliczne, a nieraz nie świadczyły o aktywności zawodowej (np. armia czynna, rentierzy, pozostajacy w zakładach opiekuńczych, osoby bez podania konkretnego źródła utrzymania).

Uzyskany w ten sposób obraz ukazuje, że w początkach XX w. preferencje zawodowe ludności pracującej w Galicji z pominięciem rolnictwa, służby cywilnej i wolnych zawodów pozostawały zbliżone bez względu na wiek. Model zawodowy stabilizował się począwszy od grupy 30-latków. $\mathrm{Z}$ wiekiem ograniczeniu ulegało zatrudnienie $\mathrm{w}$ gałęziach takich jak górnictwo i hutnictwo, przerób metali czy komunikacja, a wzrastało w handlu. Można również przypuszczać, że ten sam schemat realizował się w 1910 r. Poza rolnictwem osoby w wieku 60+ w największym stopniu partycypowały w handlu, wytwórczości odzieży (rozumianej również w kategoriach usług), a także artykułów spożywczych i napojów. Te cztery działy zatrudniały blisko $70 \%$ ludności z sektorów pozarolniczych objętych badaniem. Dla kobiet po 60. roku życia ich znaczenie 
Wykres 4. Liczba ludności Galicji w 1910 r. zatrudnionej w głównych sektorach według grup wiekowych

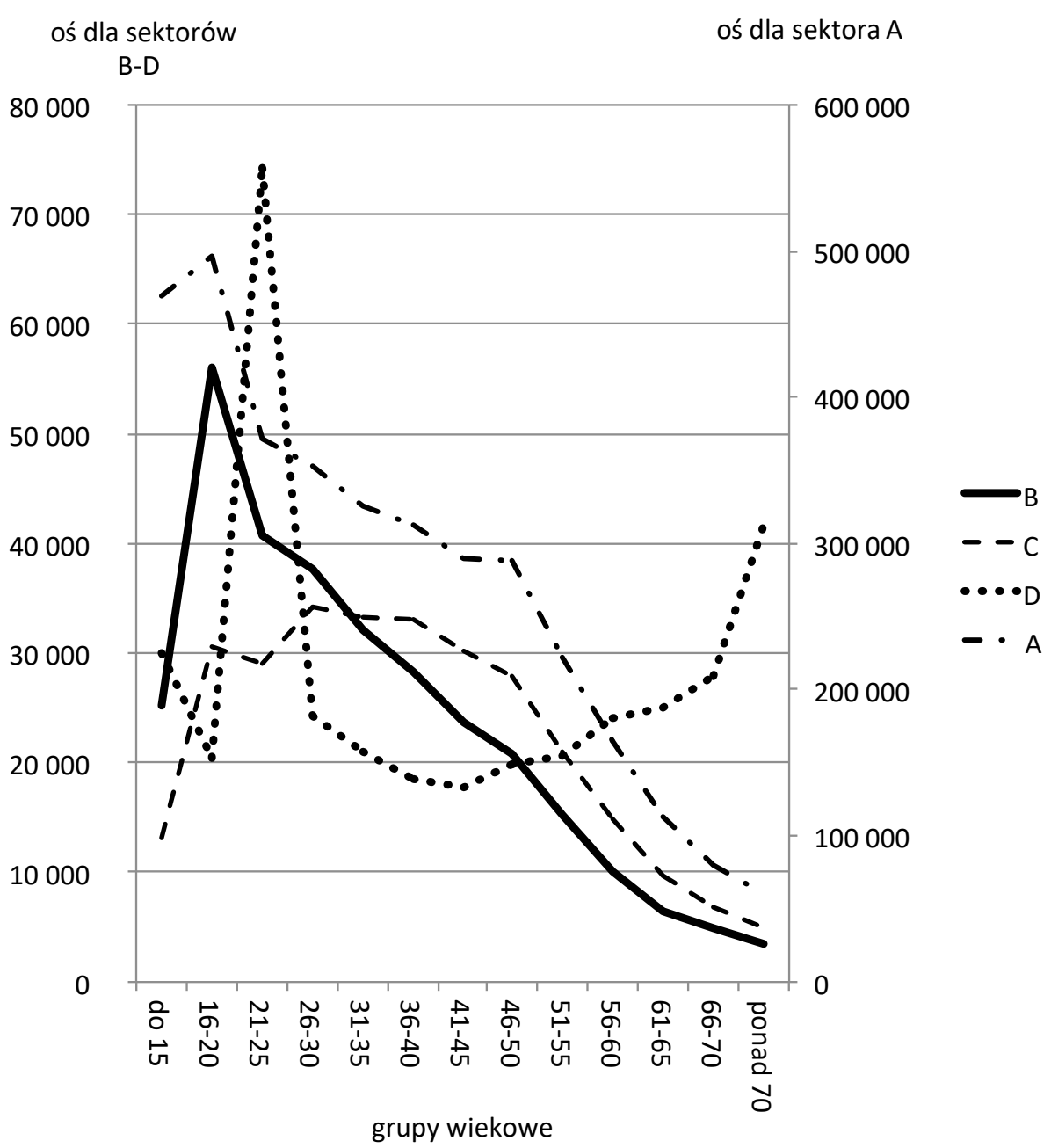

Legenda: A - rolnictwo, hodowla, leśnictwo, B - rzemiosło i przemysł, C - handel i komunikacja, D - służba publiczna, wojsko, wolne zawody, na zasiłku.

Źródło: zob. wykres 2.

było jeszcze większe, wyrażając się wskaźnikiem aż 90\%, przy czym prawie połowa $\mathrm{z}$ nich pracowała $\mathrm{w}$ handlu.

W przypadku osób starych gałęzie te mogły być atrakcyjne, ponieważ nie wymagały znacznych nakładów inwestycyjnych (np. szewstwo przybierające w pewnych regionach Galicji charakter masowy ${ }^{45}$ ).

${ }^{45}$ S. Kot, Wspomnienia, „Zeszyty Historyczne” 1967, nr 12, s. 164. 
Wykres 5. Struktura zatrudnienia w sektorze B i C w 1900 r. według grup wiekowych

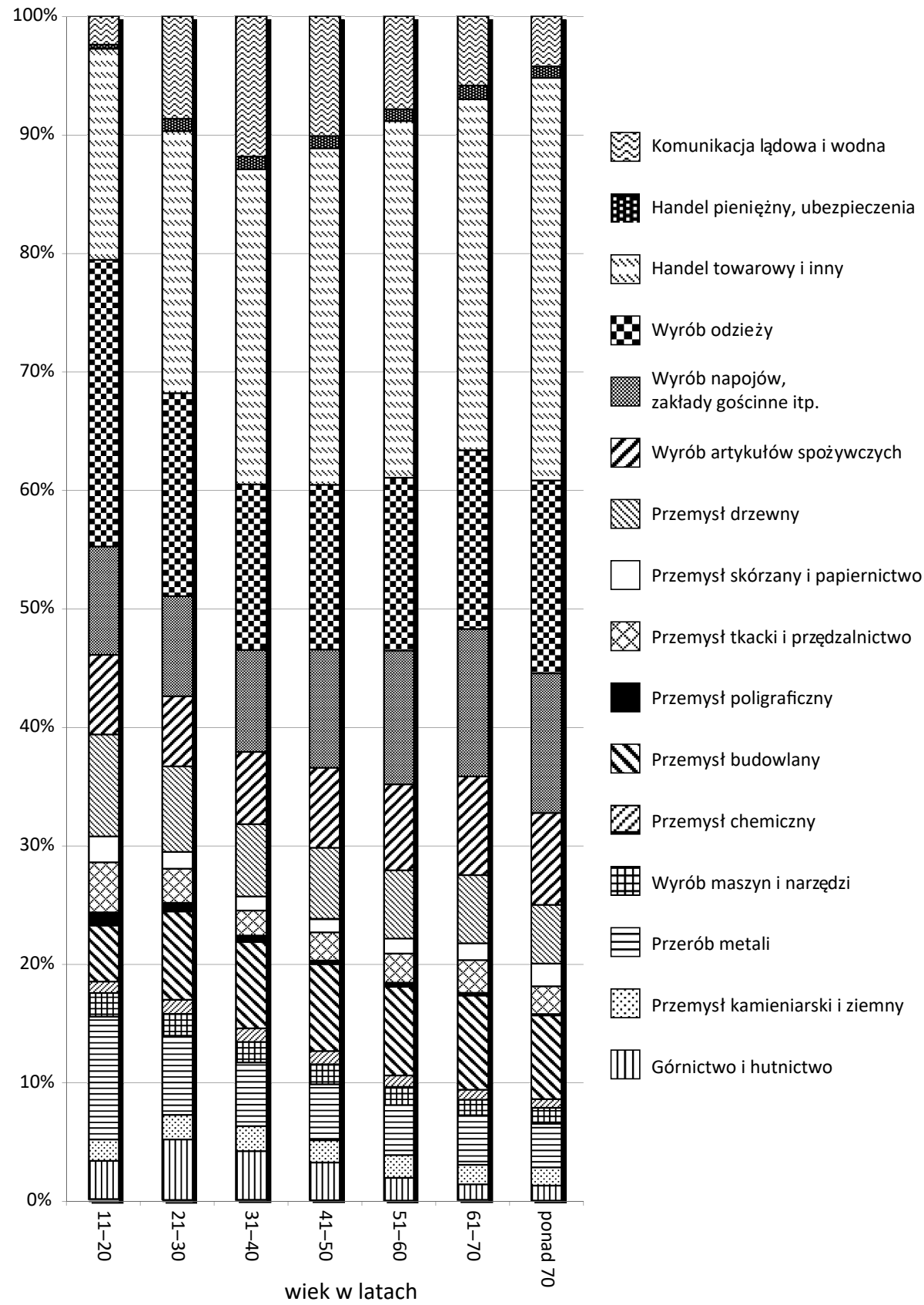

Źródło: zob. wykres 1. 
Niestety charakter źródła w tym akurat obszarze wyklucza dokładne analizy. Nie da się, korzystając z tych danych, ukazać specyfiki regionalnej, zależności wynikających z poziomu urbanizacji itp. Można jednak założyć, że podobnie jak w przypadku rolnictwa w wielu przypadkach oddziaływała tu ta sama siła napędowa - konieczność zapewnienia środków do życia przy posiadaniu pewnych umiejętności oraz ograniczonych możliwościach inwestycyjnych. Stąd zarówno drobny handel, jak i drobne rzemiosło, określane w Galicji mianem „przemysłu domowego”, wydaja się naturalna enklawa ekonomiczna stanowiąca punkt docelowy dla seniorów. Znamiona tak rozumianej aktywności wyczerpuje swoisty model zatrudnienia charakteryzujący się minimalną koncentracją i zaangażowaniem co najwyżej małżonka lub kogoś z młodszych członków rodziny. Więcej światła na tę kwestię rzuci analiza struktury zawodowej pod względem stosunku do pracy (zob. wykres 6, tab. 2).

\section{Ludność w wieku 60+ według stosunku do pracy}

Ludność pracująca w Galicji dzielono na cztery kategorie: tzw. pomagających członków rodziny (o których była już mowa), tzw. samodzielnych (inaczej samoistnych), tzn. osoby będące kierownikami gospodarstw, zakładów lub tworzące miejsca pracy dla siebie czy też innych, pracowników umysłowych oraz robotników. Proporcje między poszczególnymi kategoriami możemy obserwować na wykresie 6 . Jak z niego wynika, wśród zamieszkujacych Galicję w 1910 r. osób pracujących powyżej 60. roku życia największy był udział tzw. samodzielnych. Szczególnie interesujace jest to zjawisko na tle pozostałych grup wiekowych, sprawia bowiem wrażenie jakoby samodzielność zawodowa wzrastała z wiekiem. Ponad połowa czynnych zawodowo między 41. a 45. rokiem życia to samodzielni, a w kolejnych przedziałach wiekowych ich udział zwiększał się jeszcze bardziej. Między 61. a 65. rokiem osiagnał już $65 \%$, a po 70 . roku życia nawet ok. $75 \%$. Przy takich rozmiarach trudno mówić o marginalizowaniu czy nawet wykluczeniu ludzi starych z rynku pracy. Aczkolwiek niewatpliwie tendencje takie mogły się ujawniać w wybranych specyficznych grupach, to raczej nie były normą powszechnie występujacca. W największym stopniu zagrożone były kobiety, których udział wśród samodzielnych po przekroczeniu 60. roku życia okazał się w porównaniu do mężczyzn znacznie mniejszy.

Pomimo to „samodzielność zawodowa” rosła wśród kobiet $\mathrm{z}$ wiekiem, podobnie jak u mężczyzn, i to na dużą skalę (zob. wykres 6). Jeśli bowiem 


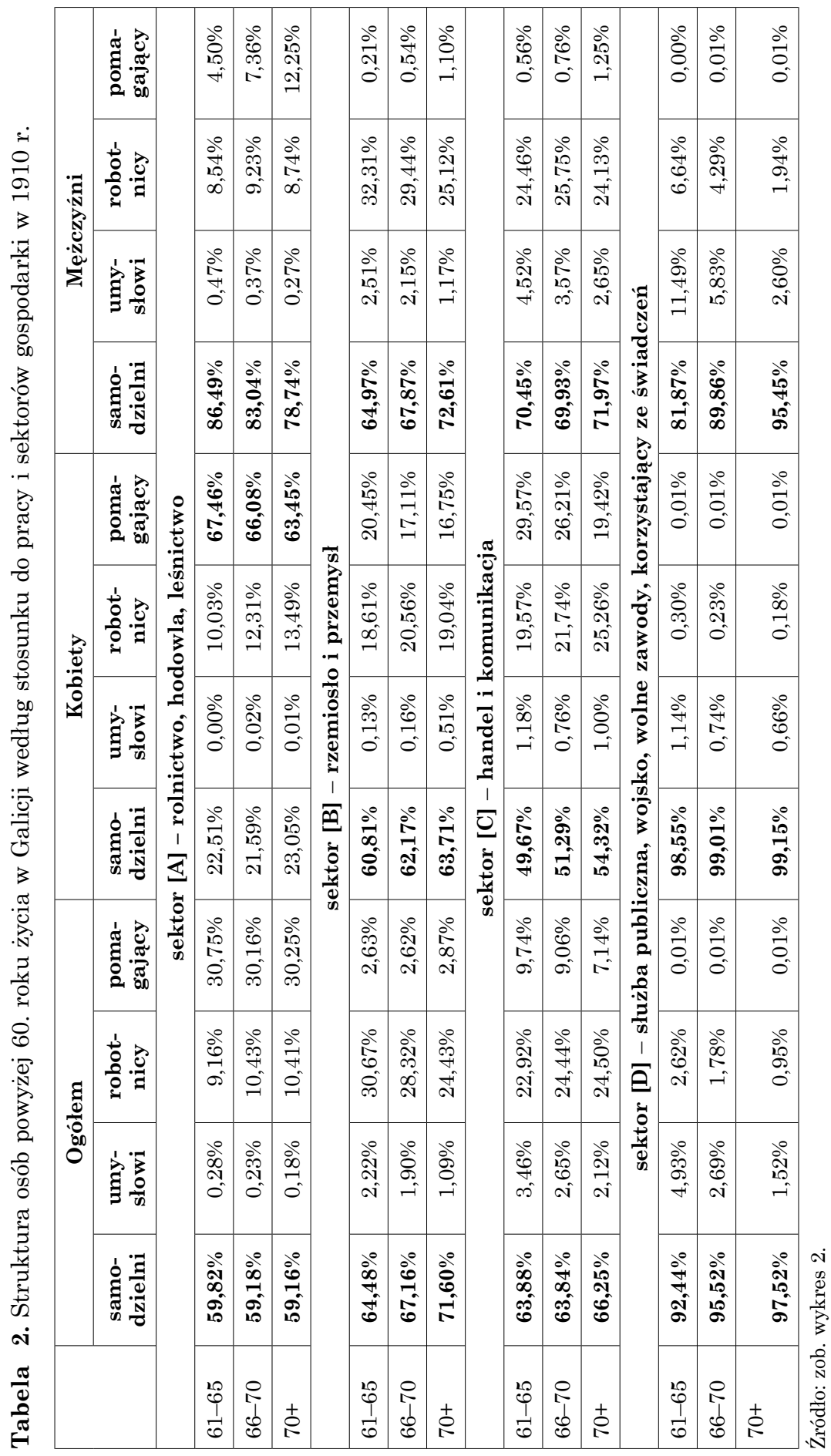


Wykres 6. Ludność Galicji pod względem stosunku do pracy w 1910 r.
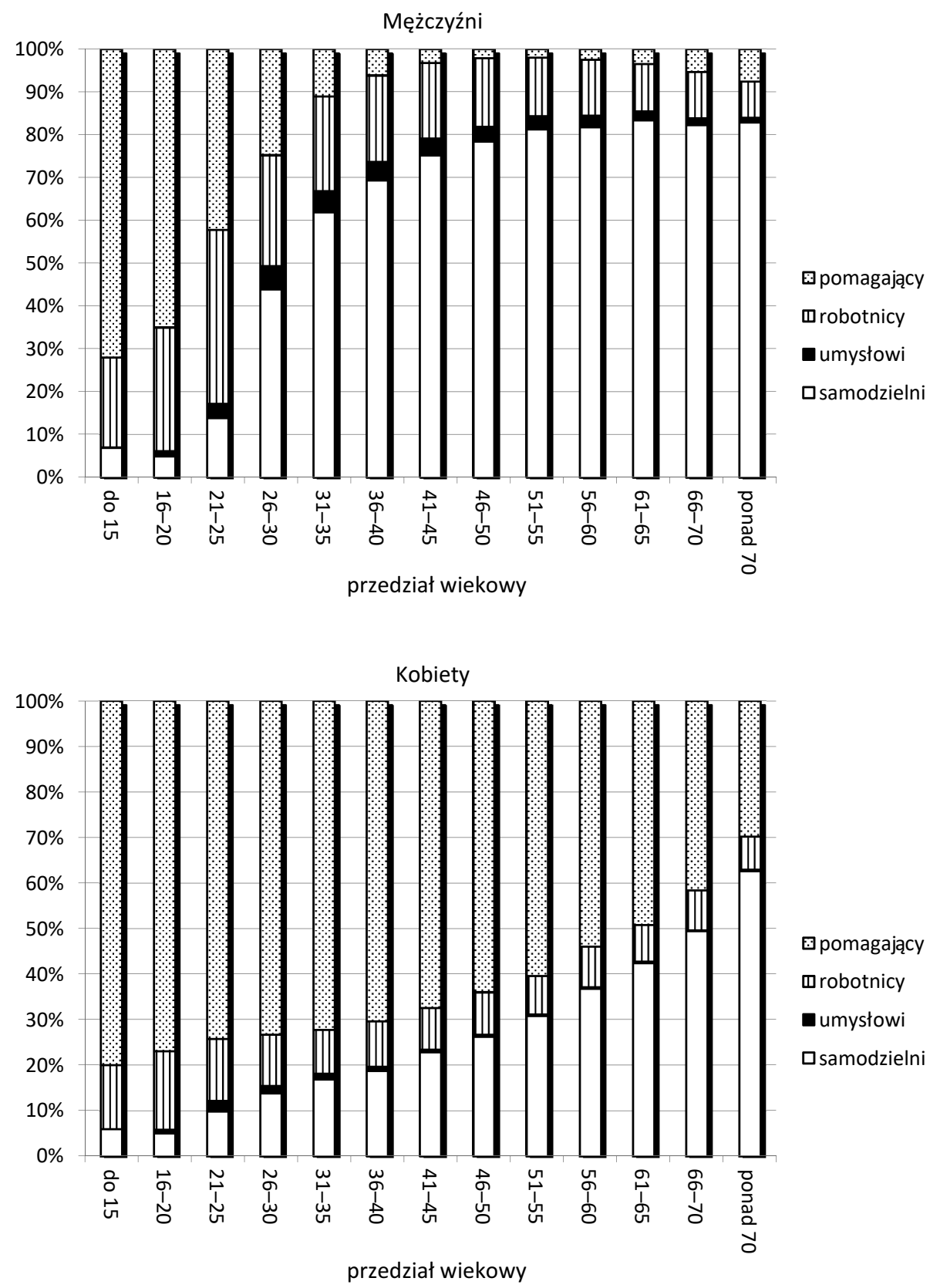

Źródło: zob. wykres 2. 
w grupie osób w wieku 61-65 lat samodzielne kobiety stanowiły ponad $40 \%$, to w grupie $70+$ już ponad $60 \%$ (w młodszych grupach wiekowych wskaźnik ten był niższy - między 40. a 50. rokiem życia osiagał rozmiary rzędu 20-30\%).

Odwrotnie zjawisko to kształtowało się w grupie tzw. pomagajacych członków rodziny. Szczegółowe obliczenia na podstawie materiału zamieszczonego na łamach „Österreichische Statistik” pokazały, że bez względu na płeć ich udział spadał poniżej połowy wśród osób między 26. a 30. rokiem życia i z wiekiem zmniejszał się jeszcze bardziej, osiagając w grupie wiekowej 61-65 ok. 23\%. Pozostałe kategorie ludności czynnej zawodowo (poza samodzielnymi i pomagającymi) również cechowała tendencja spadkowa, choć o nieco łagodniejszym przebiegu. Szczególnie widać to na przykładzie robotników, których znaczenie wzrastało w grupach wiekowych do 25 . roku życia (30\%), a następnie bardzo powoli zaczynało się obniżać, osiagajac po 60. roku życia 10\% i mniej. Wśród kobiet rola osób pomagających była zdecydowanie większa. W grupie wiekowej do 15 . roku życia stanowiły one $80 \%$, ale ze stała tendencja spadkowa, która pogłębiała po osiagnięciu 40 lat (zob. wykres 6).

Struktura tak rozumianej aktywności zawodowej różniła się w zależności od sektora gospodarki galicyjskiej (co ukazuje tab. 2). W rolnictwie ogólny udział samodzielnych wśród osób po 60. roku życia osiagną wskaźnik $60 \%$. Był to co prawda wynik wyższy niż w młodszych grupach wiekowych, ale lokujący ten sektor na ostatnim miejscu w porównaniu z pozostałymi. O specyfice rolnictwa decydowało jednak coś jeszcze. Kobiety jako samodzielne właścicielki stanowiły tu zaledwie 20\%, podczas gdy $\mathrm{w}$ roli pomagających członków rodziny osiagnęły wskaźnik aż 65\%. Takich dysproporcji nie odnajdziemy w żadnym z pozostałych sektorów - B, C i D, choć ogólna tendencja przejawiająca się rosnacym z wiekiem znaczeniem samodzielnych (bez względu na płeć) daje się zauważyć również poza rolnictwem. We wszystkich sektorach towarzyszył jej też proporcjonalny spadek udziału osób pomagajacych. Odmiennie niż w rolnictwie, w sektorach pozarolniczych kobiety $\mathrm{w}$ zdecydowanie większym stopniu obejmowały stanowiska samodzielne (zob. tab. 2). Choć nie dorównywały pod tym względem mężczyznom, to jednak samodzielność zawodową po 60. roku życia osiagała co druga $z$ nich.

Jednym z czynników wpływajacych na obraz zatrudnienia był stan cywilny. Wśród samodzielnych - jako proporcjonalnie najliczniejszej kategorii pracujących po 60. roku życia - najbardziej charakterystycznym zjawiskiem był duży, w dodatku rosnący $\mathrm{z}$ wiekiem udział osób 
samotnych (wynosząc w 5-letnich przedziałach wiekowych po 60. roku życia odpowiednio 38 , 42 i $57 \%)^{46}$.

W przypadku mężczyzn związek samotności z aktywizacją zawodową był jednak dużo słabszy. Według danych z 1910 r. po 60. roku życia aż $80 \%$ samodzielnych stanowili żonaci. Wskaźnik ten malał jednak z wiekiem z przyczyn naturalnych (po 70. roku życia 40\% samodzielnych mężczyzn było samotnych). Dla porównania samotne kobiety po przekroczeniu 40. roku życia stanowiły praktycznie połowę samodzielnych (41\% to wdowy), a w grupie $60+$ aż od 80 do nawet $90 \%$. Oczywiście, by tak pojmowana niezależność stała się gwarantem samorealizacji zawodowej spełnione musiało być jeszcze wiele warunków, w tym odpowiednia pozycja ekonomiczna jako jeden $\mathrm{z}$ ważniejszych ${ }^{47}$.

W pierwszej dekadzie XX w. dostrzegalne było też inne zjawisko aktywizacja zawodowa kobiet, których samotność nie wypływała z wdowieństwa. Ich udział wśród samodzielnych po 60. roku życia wahał się na poziomie kilkunastu procent. W liczbach bezwzględnych nie były to wielkości imponujące, niecałe dwieście w rzemiośle, kilkaset w obszarze handlu i tyle samo w rolnictwie (gdzie w proporcji do wdów i mężatek osiagały zaledwie 3,5\%). Najwięcej - ok. 6,5 tys. - było ich jednak w sektorze D. Obok kobiet pobierajacych różnego rodzaju zasiłki w niemałej części mogły to być nauczycielki zatrudnione na różnych szczeblach szkolnictwa galicyjskiego, choć tutaj dane spisowe nie sa na tyle precyzyjne, by z całą stanowczością wyciagać takie wnioski.

$* * *$

Ciekawych spostrzeżeń dostarczyć może jeszcze porównanie Galicji z pozostałymi krajami koronnymi Habsburgów (zob. tab. 3). W obrębie tej części monarchii widoczne staje się znaczne zróżnicowanie podstawowych parametrów, uznanych przez nas jako markery aktywności zawodowej seniorów. Zróżnicowanie to odpowiada w pewnym sensie polaryzacji gospodarczej między wschodnia a zachodnią częścią Przedlitawii. Prawie wszystkie porównywane wskaźniki w przypadku Galicji odstaja od średniej, ciążąc ku takim krajom jak Dalmacja czy Bukowina. Jeszcze wyraźniejszy dystans dzieli ją od krajów bardziej uprzemysłowionych (Czechy, Morawy), choć niekiedy zauważyć można podobieństwa.

46 Obliczenia własne na podstawie: „Österreichische Statistik” 66, 1904, nr 11, s. 182-205; „Österreichische Statistik. Neue Folge” 3, 1916, nr 10, s. 206-221.

${ }^{47}$ Obliczenia własne na podstawie: „Österreichische Statistik” 66, 1904, nr 11, s. 182-205; „Österreichische Statistik. Neue Folge” 3, 1916, nr 10, s. 206-221. 
Pod względem demograficznym w początkach XX w. społeczeństwo zaboru austriackiego jawi się na tym tle jako jedno z najmłodszych ${ }^{48}$. Pomimo to proporcjonalny udział osób $\mathrm{w}$ wieku 60+ $\mathrm{w}$ grupie pracujacych jest zbliżony do średniej charakteryzującej wszystkie porównywane kraje. Bardzo wysokie okazuja się natomiast wskaźniki zatrudnienia w obrębie samej grupy 60+. Podobne wyniki osiagnęły wówczas Dalmacja, Kustenland oraz Bukowina, a więc obszary najsłabiej uprzemysłowione. Równocześnie w grupie nieaktywnych zawodowo osób w wieku 60+ zdumiewająco niewielki jest w Galicji udział korzystających z zasiłków, rent i emerytur.

Tabela 3. Ludność aktywna zawodowo w wieku 60+ w 1900 r. w austriackich krajach koronnych

\begin{tabular}{|c|c|c|c|c|}
\hline Kraj & $\begin{array}{c}\text { Wskaźnik } \\
\text { starości }\end{array}$ & $\begin{array}{c}\text { Osoby pracu- } \\
\text { jące 60+ } \\
\text { w proporcji do } \\
\text { ogółu pracują- } \\
\text { cych }\end{array}$ & $\begin{array}{c}\text { Osoby pracu- } \\
\text { jące w pro- } \\
\text { porcji do nie- } \\
\text { pracujących } \\
\text { w grupie } 60+\end{array}$ & $\begin{array}{c}\text { Udział osób } \\
\text { korzystających } \\
\text { z rent i zasił- } \\
\text { ków wśród } \\
\text { niepracują- } \\
\text { cych w wieku } \\
60+\end{array}$ \\
\hline Austria Górna & $10,31 \%$ & $10,79 \%$ & $60,82 \%$ & $63,50 \%$ \\
\hline Austria Dolna & $7,39 \%$ & $7,34 \%$ & $53,38 \%$ & $54,57 \%$ \\
\hline Bukowina & $4,92 \%$ & $7,32 \%$ & $72,19 \%$ & $22,43 \%$ \\
\hline Czechy & $8,07 \%$ & $8,75 \%$ & $53,97 \%$ & $56,86 \%$ \\
\hline Dalmacja & $8,18 \%$ & $10,90 \%$ & $78,58 \%$ & $13,76 \%$ \\
\hline Galicja & $5,90 \%$ & $8,60 \%$ & $78,39 \%$ & $19,09 \%$ \\
\hline Karyntia & $8,81 \%$ & $8,91 \%$ & $61,21 \%$ & $71,16 \%$ \\
\hline Kraina & $9,40 \%$ & $10,28 \%$ & $65,33 \%$ & $67,96 \%$ \\
\hline Kustenland & $8,89 \%$ & $12,54 \%$ & $77,54 \%$ & $28,46 \%$ \\
\hline Morawy & $7,88 \%$ & $8,52 \%$ & $56,96 \%$ & $64,79 \%$ \\
\hline Salzburg & $8,68 \%$ & $9,06 \%$ & $62,21 \%$ & $60,42 \%$ \\
\hline Styria & $9,25 \%$ & $10,14 \%$ & $68,59 \%$ & $66,17 \%$ \\
\hline Śląsk & $6,68 \%$ & $7,06 \%$ & $52,85 \%$ & $57,25 \%$ \\
\hline Tyrol i Vorarlberg & $9,72 \%$ & $12,87 \%$ & $80,12 \%$ & $25,92 \%$ \\
\hline Średnia & $8,15 \%$ & $9,50 \%$ & $65,87 \%$ & $48,02 \%$ \\
\hline
\end{tabular}

Źródło: „Österreichische Statistik” 66, 1903, nr 2-4, passim; „Österreichische Statistik” 66, 1904, nr 5-12, passim; K. Zamorski, Informator statystyczny do dziejów społeczno-gospodarczych Galicji. Ludność Galicji w latach 1857-1910, Kraków-Warszawa 1989, passim.

${ }^{48}$ Szerzej zob. K. Zamorski, Transformacja demograficzna $w$ Galicji na tle przemian ludnościowych innych obszarów Europy środkowej $w$ drugiej połowie XIX $i$ na poczatku XX w., Kraków 1991, passim. 
Wyłaniający się z tego zestawienia obraz ukazuje sytuację seniorów zamieszkujacych Galicję w niezbyt optymistycznym świetle, przesuwając akcenty $\mathrm{w}$ stronę jeszcze większych skrajności. W tym kontekście charakter aktywności zawodowej ludzi starych staje się odpowiedzią na pytanie o sposoby doświadczania starości w bardzo trudnych warunkach ekonomicznych, co może mieć już wymiar indywidualny.

\section{Zakończenie}

W świetle powyższych rozważań praca jawi się jako nieodłączny element starości. Ani granica wieku 60 lat, ani jakakolwiek późniejsza nie stanowiły tu wyraźnej bariery. Wśród najważniejszych cech wyróżniających grupę 60+, obok dużej aktywności, należy również zwrócić uwagę na charakterystyczny przekrój, w którym dominację uzyskali tzw. pracownicy samodzielni. Była to grupa najliczniejsza, stanowiąca prawie $70 \%$ zatrudnionych po 60. roku życia. W grupach młodszych (16-60 lat) wskaźnik ten był o połowę mniejszy, wynosząc ok. 35\%. Warto też zaznaczyć, że w żadnym sektorze gospodarki Galicji ich udział nie obniżał się $\mathrm{z}$ wiekiem, a wręcz przeciwnie.

Ukazany w artykule zarys pozwala na różne możliwości interpretacji. Duże doświadczenie zawodowe i życiowe, czyniące osoby starsze swego rodzaju profesjonalistami cenionymi przez pracodawcę, mogło nadawać tej swoistej wędrówce przez życie cechy awansu osiaganego w jego jesieni. Nie uzyskamy jednak odpowiedzi na pytanie, czy rodziło rywalizację międzypokoleniową i inne negatywne zjawiska towarzyszące współcześnie rynkowi pracy (wypalenie zawodowe, stres, choroby psychiczne). Wreszcie te same atuty mogły ułatwiać czy też pobudzać do przedsiębiorczości i w efekcie prowadzić do zakładania własnego biznesu. Tak mogłoby to wyglądać w wersji optymistycznej, charakterystycznej raczej dla waskich grup społeczeństwa. Z drugiej strony duża skala samodzielności wskazuje na strategię, której synonimem jest mały warsztat pracy, będący $\mathrm{w}$ istocie jednoosobowa firma, nastawiona raczej na przetrwanie, bez większych szans na sukces ekonomiczny. W realiach galicyjskich podobna interpretacja aktywności seniorów wydaje się najbardziej wiarygodna.

W takiej sytuacji zróżnicowanie społeczno-ekonomiczne cechujące Galicję w powiązaniu z uwarstwieniem społecznym mogły prowadzić do wykrystalizowania się co najmniej trzech modeli aktywności zawodowej ludzi starych. Model pierwszy realizował się w warunkach pracy na wsi. Odzwierciedlał on co prawda ogólne tendencje, ale wyraźnie akcentował cechy typowo patriarchalne. Przewaga mężczyzn była tu zdecydowanie 
większa, co wyrażało się choćby w tym, że kobiecie zarówno młodej, jak i w podeszłym wieku przypadały zajęcia pomocnicze. Przypomnijmy, jako samodzielne właścicielki gospodarstw i tworzące miejsca pracy pojawiały się one na wsi znacznie rzadziej. Nawet pozycja wdów nie była tu tak wyrazista. Model ten był dodatkowo utwierdzany tradycja i zwyczajami spadkowymi, według których gospodarstwo przechodziło na męskiego potomka. Prawdopodobnie nie następowało to zbyt szybko, ponieważ w obawie o jego podział rodzice często korzystali z dożywocia, pozostając faktycznie kierownikami gospodarstwa do późnej starości (głównie ojciec). Dopiero w grupie wiekowej po 70. roku życia dało się zauważyć przesunięcie w stronę tzw. pomagających (do ok. 12\%), choć i tak mężczyźni jako samodzielni stanowili blisko $60 \%$.

Drugi model realizował się poza rolnictwem. Zarówno dla kobiet, jak i mężczyzn po 60. roku życia praca stanowiła warunek niezbędny do przetrwania. Synonimem aktywności zawodowej mógł być mały warsztat rzemieślniczy lub stragan, aczkolwiek również i tu występowało na pewno znaczne zróżnicowanie. W odróżnieniu od wsi, kobiety w podeszłym wieku częściej pojawiały się tu wśród samodzielnych. Było tu też więcej miejsca dla typowych singli, osób będących samotnymi, ale nie za przyczyną owdowienia.

Trzeci model dotyczył kobiet. Kwestia ich aktywizacji zawodowej stanowi osobny problem, a zagadnienie pracy w wieku starczym jest jego naturalnym przedłużeniem. Źródła statystyczne zwracają uwagę na zjawisko specyficznego awansu. Można odnieść wrażenie, że przekroczenie 60. roku życia nie stanowiło schyłku ich aktywności zawodowej, ale osiagnięcie etapu dojrzałości. Ich pozycję wzmacniał tu stan samotności, w szczególności wdowieństwo, pozwalające na objęcie samodzielnego stanowiska kierowniczego (np. po zmarłym mężu).

We wszystkich opisanych sytuacjach ważnym czynnikiem różnicującym były dysproporcje majątkowe i uwarstwienie społeczne. Aktywność zawodowa nie oznaczała od razu dobrobytu, satysfakcji, samozadowolenia. Nie musiała też mieć cech samorealizacji, a starość nie gwarantowała dla tych zatrudnionych pogodnej jesieni życia. Praca mogła być jednym ze sposobów jej przeżywania czy może lepiej przetrwania. Kwestią przyszłych badań jest weryfikacja i uszczegółowienie powyższych wniosków. Zdaję sobie sprawę, że wykorzystane tu źródła statystyczne posłużyły głównie do postawienia wielu nowych pytań. Problem aktywności zawodowej ludzi starych w Galicji jest niewątpliwie częścią większego zagadnienia. Ciagle aktualne pozostają wątki związane z poszczególnymi grupami zawodowymi. Rodzą się zatem pytania o charakter ich życia codziennego czy miejsce w społeczeństwie. 


\section{Bibliografia}

Bois J.-P., Historia starości. Od Montaigne’a do pierwszych emerytur, tłum. K. Marczewska, Warszawa 1996.

Borkowska-Kalwas T., Aktywność zawodowa ludzi starych, w: Starzy ludzie $w$ Polsce. Społeczne i zdrowotne skutki starzenia się społeczeństwa, red. J. Halik, Warszawa 2002.

Broński K., Rozwój system ubezpieczeń społecznych w Galicji w XIX wieku (zarys problematyki), „Zeszyty Naukowe Uniwersytetu Ekonomicznego w Krakowie" 2010, nr 824, s. 5-24.

Burzyński A., Statystyka austriacka i krajowa jako źródto do badań nad strukturq społeczno-zawodowa zatrudnionych $w$ przemyśle ciężkim $w$ Galicji, „Studia Historyczne” 26, 1983, nr 2 (101), s. 223-242.

Burzyński A., Z rozważań nad ocenq austriackich powszechnych spisów ludności z lat 1869-1919, „Przeszłość Demograficzna Polski” 15, 1984, s. 58-69.

Ciara S., Starość ludzi nauki w Krakowie i Lwowie w końcu XIX $i$ w pierwszej ćwierci XX wieku (na wybranych przyktadach), w: Ludzie starzy i starość na ziemiach polskich od XVIII do XXI wieku (na tle porównawczym), t. 2, red. A. Jasińska-Janiak, K. Sierakowska, A. Szwarc, Warszawa 2016, s. 65-71.

Gapiński B., Ludzie starzy na wsi polskiej od schytku XIX wieku po rok 1939, Poznań 2014.

Gąsowski T., Austriackie spisy ludności z lat 1869-1910, „Przeszłość Demograficzna Polski” 13, 1981, s. 37-48.

Jarosz-Nojszewska A., Ubezpieczenia pracowników umystowych w Drugiej Rzeczypospolitej, w: Od kwestii robotniczej do nowoczesnej kwestii socjalnej. Studia z polskiej polityki spolecznej XX $i$ XXI wieku, red. P. Grata, Rzeszów 2017, s. 34-50.

Kot S., Wspomnienia, „Zeszyty Historyczne” 1967, nr 12, s. 163-178.

Kozak S., Kierunki aktywizacji zawodowej kobiet w Galicji w końcu XIX i na poczatku XX wieku w świetle spisów ludności „Zeszyty Naukowe UJ. Prace Historyczne" 2019, z. 146, nr 1, s. 101-128.

Kozak S., Kobieta na prowincji galicyjskiej $w$ świetle akt notarialnych 1871-1914. Studium historyczno-źródtoznawcze, Rzeszów 2013.

Kruk D.P., Instytucjonalne formy wspierania rozwoju przemystu Galicji w dobie autonomii, „Zeszyty Naukowe Uniwersytetu Ekonomicznego w Krakowie” 2015, nr 6 (942), s. 93-105.

Libertowska A., Sytuacja osób $w$ wieku 50+ na rynku pracy $w$ Polsce wobec przemian demograficznych, „Zeszyty Naukowe Politechniki Poznańskiej” 2017, nr 75, s. 163-176.

Ludzie starzy $i$ starość na ziemiach polskich od XVIII do XXI wieku (na tle porównawczym), t. 1-2, red. A. Jasińska-Janiak, K. Sierakowska, A. Szwarc, Warszawa 2016.

Majewska M., Przybylczak K., Aktywność zawodowa osób starszych warunkiem utrzymania produktywności w krajach gospodarczo rozwiniętych, „Studia i Prace WNEiZ US” 2018, nr 52/3, s. 221-231. 
Nietyksza M., Ramy prawne zarobkowania kobiet $w$ Królestwie Polskim $w$ XIX i na poczatku XX w. na tle porównawczym, w: Kobieta i praca. Wiek XIX i XX. Zbiór studiów, t. 6, red. A. Żarnowska, A. Szwarc, Warszawa 2000, s. 15-28.

Niewiadomska A., Aktywność zawodowa osób starszych w wybranych krajach Europy Środkowej, „Ekonomia XXI wieku” 2016, nr 3 (11), s. 311-326.

Pikuła N.G., Rozwój zawodowy $i$ zawodowa satysfakcja w perspektywie osób starszych, „Labor et Educatio” 2016, nr 4, s. 201-217.

Podogrodzka M., Wybrane miary starości demograficznej i ich implikacje dla oceny przestrzennego zróżnicowania tego zjawiska w Polsce, „Studia Ekonomiczne. Zeszyty Naukowe Uniwersytetu Ekonomicznego w Katowicach” 2016, nr 289, s. 98-107.

Pudłocki T., Czy na pewno starzy? Obraz profesorów i nauczycieli szkót średnich Galicji $z$ drugiej połowy XIX $i$ poczqtku XX wieku w oczach ich uczniów, w: Ludzie starzy $i$ starość na ziemiach polskich od XVIII do XXI wieku (na tle porównawczym), t. 2, red. A. Jasińska-Janiak, K. Sierakowska, A. Szwarc, Warszawa 2016, s. 325-337.

Reymont W., Ziemia obiecana, wyd. 1, Warszawa 1899 (i kolejne wydania). Rocznik statystyczny pracy, Warszawa 2015.

Stan $i$ struktura ludności oraz ruch naturalny $w$ przekroju terytorialnym w 2014 r. Stan w dniu 31 XII, Warszawa 2015.

Staręga J., Ludzie starzy a praca zawodowa, Warszawa 1976.

Suesser I., Prawa i obowiazki robotników wedtug ustaw austriackich, Kraków b.d.w.

Tomczyk R., Pragmatyka stużbowa ze szczególnym uwzględnieniem prawodawstwa płacowo-emerytalnego $w$ monarchii konstytucyjnej $w$ Austrii przed duża nowelizacja w 1914 roku, „Zeszyty Naukowe Uniwersytetu Rzeszowskiego. Seria Prawnicza” 2013, nr 77, s. 154-182.

Tomczyk R., Prawo pracownicze $w$ dobie industrializacji $w$ monarchii habsburskiej, „Historia Slavorum Occidentis” 2016, nr 1 (10), s. 167-187.

Tymiński M., Koryś P., Struktura zawodowa ziem polskich na przełomie XIX i XX w., RDSG, t. 75, 2015, s. 129-166.

Zamorski K., Informator statystyczny do dziejów społeczno-gospodarczych Galicji. Ludność Galicji w latach 1857-1910, Kraków-Warszawa 1989.

Zamorski K., Transformacja demograficzna $w$ Galicji na tle przemian ludnościowych innych obszarów Europy środkowej $w$ drugiej połowie XIX $i$ na poczatku XX w., Kraków 1991.

Zyblikiewicz L.A., Ludność Krakowa w drugiej połowie XIX wieku. Struktura demograficzna, zawodowa $i$ społeczna, Kraków 2014.

Zyblikiewicz L.A., Powszechne spisy ludności w monarchii Habsburgów, w: Celem nauki jest człowiek... Studia z historii społecznej $i$ gospodarczej ofiarowane Helenie Madurowicz-Urbańskiej, red. P. Franaszek, Kraków 2000, s. 387-400.

Żarnowska A., Praca zarobkowa kobiet $i$ ich aspiracje zawodowe $w$ środowisku robotniczym i inteligenckim na przetomie XIX $i$ XX wieku, w: Kobieta i praca. Wiek XIX $i$ XX. Zbiór studiów, t. 6, red. A. Żarnowska, A. Szwarc, Warszawa 2000, s. 29-52. 
Szczepan Kozak

Professional activity of the elderly in Galicia in the early twentieth century. Statistical overview

(Summary)

In the early twentieth century, people over the age of 60 constituted less than $10 \%$ of the entire population of Galicia. As retirement schemes were only available to a small group of people, professional activity was a lifetime obligation. The article seeks to paint a picture of the professional mobilization of the elderly on the basis of the demographic's employment structure. The principal source in the analysis are the censuses of 1900 and 1910, published in the volumes of Österreichische Statistik and Österreichische Statistik. Neue Folge. Statistical analysis of the source material shows a large degree of professional mobilization of the elderly and allows to indicate its characteristic features and develop three models of professional activity among people aged 60 or over. The model for people working in the countryside differed from those working outside agriculture; the model for women was also different. In each case, the age of the individuals did not seem to limit them in their professional activities; continuity could be observed throughout the analysis, reflected for example in the similar employment structure in all age groups.

Szczepan Kozak - dr hab., prof. Uniwersytetu Rzeszowskiego, kierownik Zakładu Archiwistyki i Nauk Pomocniczych Historii Instytutu Historii tamże. Autor kilku monografii naukowych, edycji źródeł oraz kilkudziesięciu artykułów naukowych, recenzji i haseł encyklopedycznych. Redaktor i współredaktor monografii zbiorowych. Redaktor naczelny czasopisma „Galicja. Studia i Materiały”, członek redakcji czasopism „Kresy Południowo-Wschodnie” oraz „Przemyskie Zapiski Historyczne”. Zainteresowania badawcze: historia społeczna, źródłoznawstwo, archiwistyka, historia regionalna.

Szczepan Kozak - PhD with habilitation, professor at the University of Rzeszów. Head of the Department of Archival Studies and History Sub-Disciplines at the Institute of History, University of Rzeszów. Author of several monographs, source editions, and several dozen academic articles, reviews, and encyclopedic entries. Editor and co-editor of collective monographs. Editor-in-chief of the periodical Galicja. Studia i Materiaty, member of the editorial staff of periodicals Kresy Południowo-Wschodnie and Przemyskie Zapiski Historyczne. Academic interests: social history, source studies, archival studies, regional history.

E-mail: szczepan.kozak@me.com. 